原田建治、伊藤雅英、谷田貝豊彦＼cjkstart筑波大学物理工学系＆筑波大学先端学際領域研究センター

Kenji Harada, Masahide Itoh and Toyohiko Yatagai

Institute of Applied Physics, University of Tsukuba \& Tsukuba Advanced Research Alliance

1. はじめに

新しい世紀、高度情報化社会を迎えるにあたって、光技術は、その基盤技術として脚光を浴びている。しかし、従来の光応用は、光のエネ ルギー忘用、光の干涉性の利用、光の高帯域性の利用といった面が中心であり、光の 2 次元並列性を実用に生かした例は、必ずしも多くはな い。これは、光の空間的な特性を高速かつ効率よく変調する技術が存在していなかったからである。

従来の光変調素子用の非線形光学材料としては、液晶、半導体材料、無機誘導体結晶等が使用されてきた。ここで開発する素子は、有機非 線形材料を用い、従来材料では困難であった、高効率高性能空間光変調素子を開発するものである。現在まで開発されている空間光変調素子 は、液晶空間光変調器に代表されるように、低解像度で、忘答速度も、ミリ秒程度と遅く、高解像度の画像を高速に表示する必要のある分野、 例えば、マルチメディア用の立体ディスプレイや動画ホログラムディスプレイの応用には、はなはだ不適当であった。有機非線形光学材料は、 加工が容易であり、構造の設計、最適化が可能で、これとシリコン集積化回路との組み合わせにより、多機能化も可能となる。このデバイス が実用化されれば、従来の受動的な適応光学の能動化、並列処理に不可欠の光インターコネクションの能動化をもたらし、新規な立体映像表 示法実現の可能性も生まれる。例えば、マルチメディアにおける動画並列伝送、超高速並列画像処理など、次世代の情報基盤技術の一角を構 成する技術となりうるものである。さらに、この技術は、単に波面の制御ばかりでなく、光の振幅変調、波長変調技術にも当然応用可能であ り、極めて広範な光エレクトロニクスデバイスの概念を一変する可能性を持っている。

2. 有機非線形光学材料を用いた空間光変調素子

有機非線形光学材料は一般に非線形感受率が大きく、高速応答が可能である。さら に分子、結晶レベルでの設計、合成が可能であり、光エレクトロニクスの様々な分野 での応用が期待される。大きな非線形感受率と安定性に優れた非線形光学材料に関す る研究は数多く行われているが、非線形光学材料を用いたデバイス、特に空間光変調 素子の研究はほとんど行われていないのが現状である。現在までに開発されている空 間光変調素子は、液晶に代表されるように、低解像度で、応答速度もミリ秒程度と遅 く、高解像度の画像を高速に表示する必要がある分野、例えば、マルチメディア用の 立体ディスプレイや動画ホログラムディスプレイの忘用には不適当であった。高速、 高解像度の実時間光波マニピュレーションデバイスの開発が望まれている。

本研究において、有機非線形光学材料を用いた空間光変調素子の開発を検討した。 図 1 に、電気アドレス形空間光変調素子の概念図を示す。このデバイスは、有機非線 形光学材料、透明電極、LSI プロセッサー等で構成され、時系列電気信号によって光 波の制御を行う。

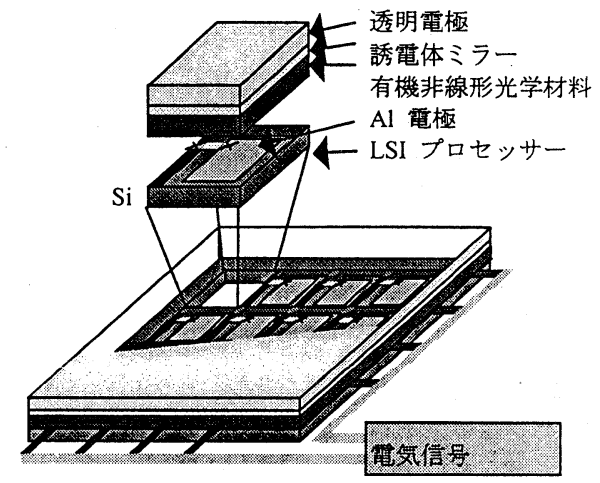

図 1 電気アドレス型空間光変調素子

3. 有機非線形光学材料の光学特性評価

デバイス応用に適する高性能有機非線形材料の評価をおこなった。有機膜の作製はスピンコート法で行い、その後色素の配向方向を揃え 2 次の非線形性を発現させるためにコロナポーリングを行った。偏光板をサンプルの前後にクロスニコル配置して、電圧印加時の He-Ne レーザ 一の偏光の回転を測定することにより 1 次の電気光学定数を測定した。アゾ色素 DR1 をドープした PMMA 及び、アゾ色素をポリマー側鎖に 導入した Poly-orange tom-1 isophoronedisocyanate (図 2)の電気光学定数はそれぞれ $r_{33}=8 \mathrm{pm} / \mathrm{V} 、 r_{33}=23 \mathrm{pm} / \mathrm{V}(633 \mathrm{~nm})$ となった。現在までに、 $r_{33}=$ $60 \mathrm{pm} / \mathrm{V}$ を超える大きな電気光学定数を示す材料も報告され、ガラス転移温度 $\mathrm{Tg}$ が $200^{\circ} \mathrm{C}$ 以上の材料では、最適なポーリング処理を施すこと により $80^{\circ} \mathrm{C} て ゙ 100$ 万時間以上安定であることをこれまでに報告した。変調効率は印加電圧に比例し、最大で $1 \%$ 程度得られた。周波数応答特 性を図 3 に示す。強誘電性液晶を淩駕する $10 \mathrm{MHz}$ の高速応答が確認できた。しかし、変調効率が小さく、これらの有機非線形材料を用いてデ バイスを実現しようとすると、制御に数千ボルトの電圧が必要となる。そこで非線形性を増加させ、低電圧で制御可能にするために、共振器 構造の使用及び、吸収領域での共鳴効果の利用を検討した。

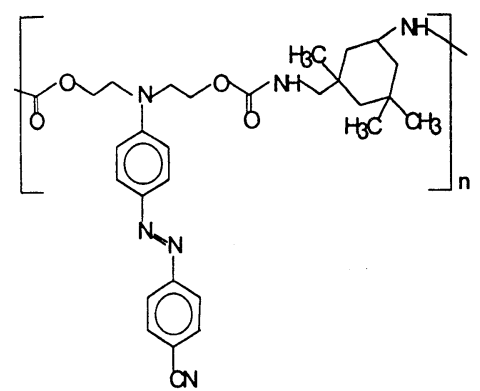

図 2 Poly-orange tom-1 isophoronedisocyanate $の$ 化学構造

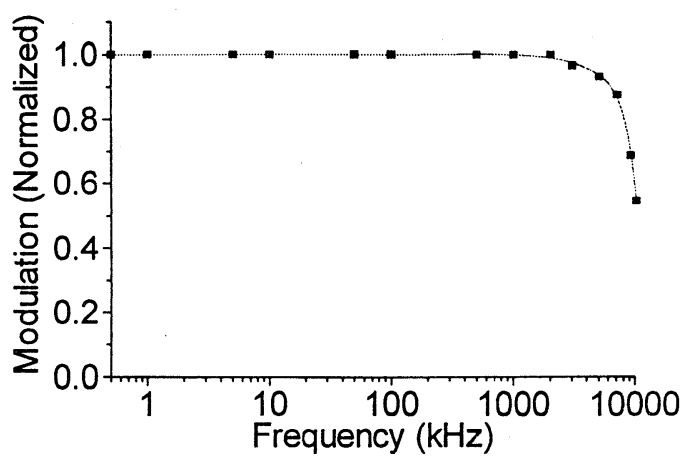

図 3 周波数応答特性 
4. 光強度変調

4.1 共振器構造による空間光変調器

非線形性を增加させ、低電圧で制御可能にするために、共振器構造の使用を 検討した ${ }^{1)}$ (図 4 )。このデバイスは $\mathrm{TiO}_{2}$ と $\mathrm{SiO}_{2}$ を光学的厚さ入/4 の厚さで交互に 積層した誘電体ミラーで、中央層のみが有機非線形光学材料で構成されており、 有機材料の膜厚と屈折率によって決まる特定の波長付近のみ透過する特性を持 っている。よって有機薄膜への電圧印加による屈折率変化により、単色光の透過 強度を制御することができる。図 5 、図 6 に、電圧印加時の透過率特性変化のシ ミュレーション結果を示す。これは、電気光学定数 $r_{33}=60 \mathrm{pm} / \mathrm{V}$ 、膜厚 $2 \mu \mathrm{m}$ の有 機薄膜を、中央層に導入した場合の透過率の計算結果であり、このデバイスに電 圧を印加すると、透明ピーク位置が図 5 のように変化する。100V の電圧印加で 約 $0.7 \mathrm{~nm}$ ピークが移動する。また $633 \mathrm{~nm}$ の波長での透過率の電圧依存性は図 6 の ようになる。層数が増加すると、より低電圧で光制御できるようになり、実験に おいても $1 \mathrm{kHz} 、 11 \mathrm{Vrms}$ の電圧印加時に、最大で 70:1 のコントラスト比が得られ た(図 7$)$ 。現在までに、デバイスの並列化 $(5 \times 5$ 素子)や、IC 上での駆動に成功し ている ${ }^{2)}$ 。

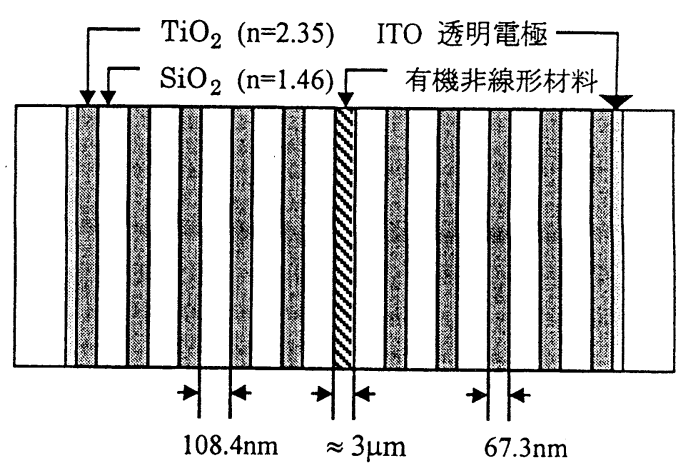

図 4 共振器構造による空間光変調器

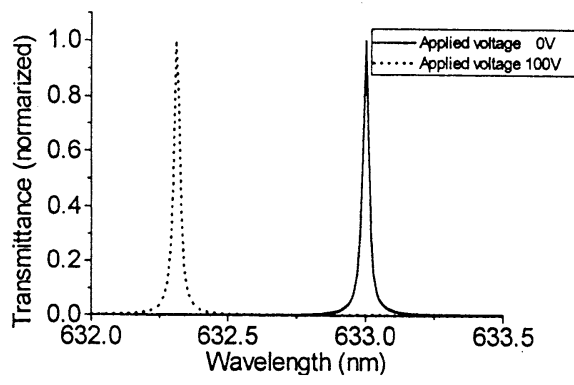

図 5 電圧印加時の透過特性の計算結果 $(r 13=20 \mathrm{pm} / \mathrm{V} \quad$ 層数 $=15$ 層 $)$

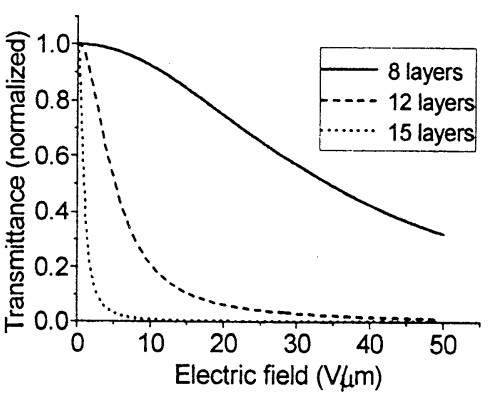

図 6 波長 $633 \mathrm{~nm}$ での電圧印加時の 透過特性の計算結果

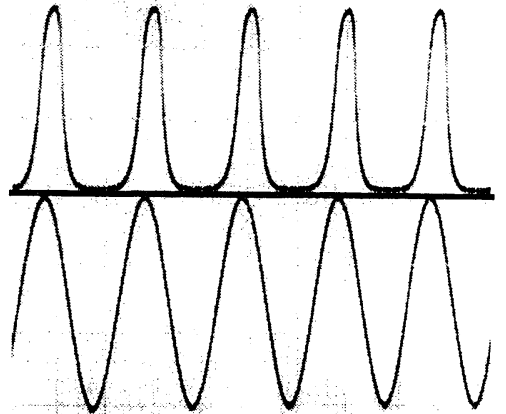

図 7 光変調結果

(下 入力 上出力 $11 \mathrm{Vrms} 、 1 \mathrm{kHz}$ )

\section{2 吸収領域における共鳴効果を利用した光変調}

有機非線形色素の吸収頒域における共鳴効果を利用すれば、電気光学定数の向上により更なる制御電圧の低減が期待できる。吸収領域での 電気光学定数、周波数応答、変調効率等を測定し、空間光変調デバイスへの適用性を検討した。実験の結果、共鳴領域では透明領域に比べ、 電気光学効果が数倍に増大され、さらに電界吸収効果による飛躍的な変調効率の増大も確認した。図 8 は、DR19 toluendi i socyanate を用い、 透明領域 $(780 \mathrm{~nm})$ 、吸収端付近 $(680 \mathrm{~nm})$ 及び吸収領域 $(633 \mathrm{~nm})$ において、電気光学定数及び電界による吸収变化を測定した結果である。図におい ては、電界吸収効果も、電気光学定数に換算し表示している。共鳴領域では、透明領域に比べ電気光学効果、電界吸収効果とも数倍に增大し、 両方の電気光学定数の和は、633nm で $r_{33}=110 \mathrm{pm} / \mathrm{V}$ 相当となり、無機結晶 $\mathrm{LiNbO}_{3}$ と比較して 3 倍以上の值が得られた。図 9 に電気光学効果と、 電界吸收効果を重ね合わせて変調した結果を示す。今後、有機材料の電気光学効果と電界吸収効果を重站合わせてコントラスト比を向上させ

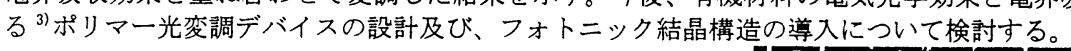

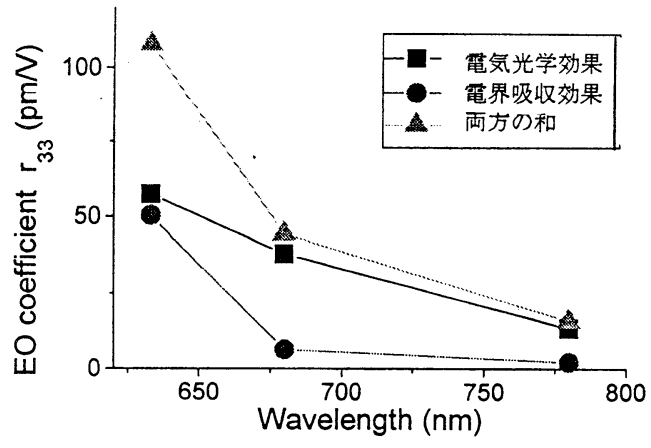

図 8 DR19 toluendiisocyanate $の$ 電気光学定数

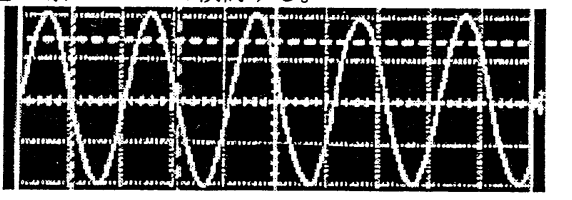

電界吸収効果+ 電気光学効果による光変調

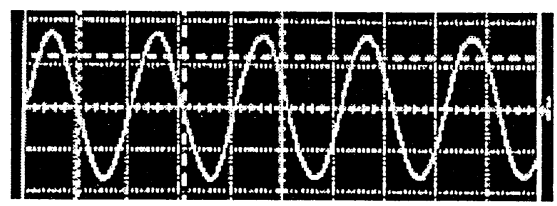

電界吸収効果一

電気光学効果による光変調

図 9 電界吸収勃果十電気光学効果による光変調結果

\section{参考文献}

1. K. Harada, M. Itoh and T. Yatagai, Development of spatial light modulators with nonlinear organic materials, Opt. Rev. 3 (1996) 440.

2. K. Harada, K. Munakata, M. Itoh, N. Yoshikawa, H. Yonezu, S. Umegaki and T. Yatagai, Poled polymer etalon light modulator on integrated circuits, Jpn. J. Appl. Phys. 37 (1998) 4393.

3. Y. Bitoh and T. Minemoto, High contrast spatial light modulator by use of the electroabsorption and the electrooptic effects in a GaAs single crystal, Appl. Opt. 37 (1998) 4347. 